\title{
The nationalist-indigenous and colonial modernity: an assessment of two sociologists in India
}

\author{
Sujata Patele
}

\author{
Correspondence: patel.sujata09@ \\ gmail.com \\ This paper is based on my earlier \\ papers on the disciplinary history of \\ sociology in India 2005, 2006, 2007, \\ 2010, 2011a, 2011b, 2013, 2015, \\ 2016, 2017, 2020b. \\ Savitribai Phule Pune University, \\ Pune, India
}

\begin{abstract}
This paper analyzes the work of two Indian sociologists who defined the contours of sociology in India in the immediate post-independence decades, M. N. Srinivas and A. R. Desai. It argues that their scholarship can be linked to sociology's legacy as anthropology in India and its embeddedness in the episteme of colonial modernity. It contends that Srinivas's methodology, the field view, attempted to make a break with earlier methods, such as book view. However, his three concepts, that of dominant caste, Sanskritization and Westernization were perceived as civilizational attributes and which had organized social change in India. A. R. Desai, a Marxist historical sociologist, made an incisive critique of capitalist exploitation and elaborated the material conditions that led to peasant and working-class revolts. However, his sociology could not unravel the caste-class linkages that organized the Indian 'social' which was embedded in Indian nationalism. This paper suggests that a definitive understanding of modernity emerges in Indian sociology in the late 70s when the feminist, dalit and tribal movements interrogated the material basis of contemporary India's developmentalism and its capitalist and exploitative character.

Keywords: Sociology of India, Nationalist-indigenous, Colonial modernity, M.N. Srinivas, A. R. Desai
\end{abstract}

\section{Introduction}

Sociology in India has had a long academic presence; it goes back about a hundred years to when the colonial government established India's first sociology department at Bombay University in 1919. This long history shows that it existed contemporarily with the early departments in Europe and the USA; the department in Chicago was established in 1892 and that in Bordeaux was established in 1895, while Max Weber set a department up in Munich in the same year that the department at Bombay University was founded. The question that needs to be asked is has this long history presented sociologists in India an opportunity to reflect on the discipline's growth and evolution, comprehend its origins in Western colonial knowledge and thereby introduce new concepts and theories to assess and analyze contemporary changes in India? This question becomes relevant given the claim that sociology, more than other social sciences,

(c) The Author(s). 2021 Open Access This article is licensed under a Creative Commons Attribution 4.0 International License, which permits use, sharing, adaptation, distribution and reproduction in any medium or format, as long as you give appropriate credit to the original author(s) and the source, provide a link to the Creative Commons licence, and indicate if changes were made. The images or other third party material in this article are included in the article's Creative Commons licence, unless indicated otherwise in a credit line to the material. If material is not included in the article's Creative Commons licence and your intended use is not permitted by statutory regulation or exceeds the permitted use, you will need to obtain permission directly from the copyright holder. To view a copy of this licence, visit http://creativecommons.org/licenses/by/4.0/. 
has within it an inherent reflexivity that allows its practitioners to interrogate the assumptions of the discipline. Thus, the following query arises: do Indian sociologists do such reflection and does this reflection allow them to define their social, cultural and professional identity as distinct from what they have inherited from colonial and Western knowledge?

I ask this question because it has been contended that in India, a vibrant social science tradition had established the contours of a critical and reflexive social science tradition since the 1940s. In economics, this has led to the exploration of poverty studies and, in political science, a search for indigenous practices of democracy. In history, there has been an affirmation of nationalist historiography together with the valorization of its key figures, such as Gandhi and Nehru, both of whose ideas and perspectives have influenced global debates on alternative modernities, democracy and social justice in different ways.

What has happened to sociology in India? What kind of critical traditions could it develop, and which ones did it develop? In 2000, Patricia Uberoi answered this question, arguing that in the past, some sociologists in India showed partiality towards a reflexive stance and questioned and probed their disciplinary proclivities. This evidence made her ask, "Why do Indian sociologists among all social scientists introspect so much publicly and so regularly about the nature of their discipline?" (Uberoi 2000:18). Introspection on the discipline, she argued, was related to doubts among sociologists in India that their positions were not free from "academic colonialism" and that this doubt incorporated a query about whether the dependence on Western theories obfuscated an understanding of Indian material and misrepresented its analysis.

Satish Saberwal (1968), who inaugurated this debate in India, discussed academic colonialism, implying that local academics contribute to such colonialism via "employment, contract research and through sheer publications used by CIA, Pentagon and other overt and covert agencies of the US government to advance its political objective of dominating Afro-Asian countries" (Saberwal 1968:10). Financial dominance, Saberwal argued, leads to academic consequences because it determines "problem selection, research design, and modes of publication” (Saberwal 1968:13). In turn, such knowledge helps influence local political processes ${ }^{1}$. Uberoi furthered her discussion on Indian sociologists' concern with 'academic colonialism' and in 2000 stated that one does "not hear... a renewed call for intellectual self-reliance, or protests against academic neo-colonialism". Surely, she argued, such an "anti-diluvian protectionism would ... be completely misplaced in a globalized culture of social scientific knowledge? Or would it?" (Uberoi 2000: 19).

In this paper, I debate this question by evaluating the contributions of two secondgeneration sociology scholars, Mysore Narasimhachar Srinivas (1916-99) and Akshay Ramanlal Desai (1915-94), who framed the discussion on social change in modern

\footnotetext{
${ }^{1}$ Saberwal was not the only one in the Asian-African context to raise this issue. In the early 1970s, the same position was taken by the Malaysian sociologist, Syed Hussein Alatas, who contended that academic dependencies have led to defects and shortcomings in social science scholarship. The "unreality" of basic Western assumptions has led to misplaced abstraction, ignorance or misinterpretation of data, and an erroneous conception of problems and their signification has led to superfluous knowledge systems. This phenomenon, which Hussein Alatas called the 'captive mind', involves scholarship uncritically emulating Western social science. The captive mind syndrome occurs when all major constituents of scientific thinking, such as problem setting, analysis, abstraction, generalization, conceptualization, description, explanation and interpretation, have been affected by this process (Alatas S.H., 1972:10-12).
} 
India in the 1950s and 1960s and whose competing positions remained popular in sociological discussions until the end of the twentieth century. Both were students of G.S. Ghurye, considered the 'father of Indian sociology' and studied with him at the Department of Sociology of the University of Bombay. I ask whether their perspectives contributed to the displacement of academic colonialism and/or academic dependen$\operatorname{cies}^{2}$ in the discipline of sociology and whether their research design and problem selection helped to provide an alternate indigenous perspective that reconstituted Western theories.

In this context, it is important to ask how we comprehend indigeneity and academic dependencies (Atal 1981). This paper contends that today, there are two positions on the theme of academic colonialism: the first defines itself as indigenous and the second defines itself as decolonial. Doing indigenous social sciences means one of the following: (a) developing social science concepts in local regional languages with the use of local resources; (b) having research conducted by insiders rather than outsiders; (c) determining research priorities in terms of 'national' priorities and, in turn, aiding the nation-state in evaluating its developmental programs and policies; and (d) attempting to formulate a new theoretical and methodological paradigm in terms of local/national philosophical and cultural legacies. This perspective emerged in the 1940s and 1950s was associated with the anticolonial movements and questioned the conceptual validity, political legitimacy and ethical grounding of post-Enlightenment Western civilization and its knowledge. Intellectuals (among them a number of Indians) who were associated with the national movement used its critique of colonialism to reconstitute social scientific practices to present a new language to study the 'social', which later came to be known as 'indigenous social science'. Indian scholars highlighted the 'difference' of their academic languages from those of the West while arguing for its grounding in a conception of 'belonging', an identity defined within a locality/geography and a territory for formulating a community/nation-based knowledge of the 'social' (Deshpande 2007). It is no wonder that this perspective became the basis for the establishment of a nationalist social science in postindependence India (Patel 2006).

In most countries, including India, doing indigenous social science means defining social science in terms of national priorities as defined by the nation state. This is translated to mean research by and for Indians, the use of regional languages to comprehend local resources, and the creation of new theories of structure and change borrowed from concepts from the West but indigenized by Indian scholars to help in understanding and representing local processes. Both scholars evaluated here used Western theories-M. N. Srinivas used the structural-functional perspective of RadcliffBrown to comprehend the changing forms and structure of the caste system, and A. R. Desai used the Marxist perspective to comprehend the specific articulation of colonial capitalism in India and evaluated the formation of distinct classes in this context. The question is did this indigenous perspective help to ensure a new reformulation of a sociological language by these two scholars?

${ }^{2}$ S. F. Alatas (2003) has reconceptualized academic colonialism to reframe it as academic dependence, which he argues has the following six characteristics: (a) dependence on ideas; (b) dependence on the media of ideas; (c) dependence on the technology of education; (d) dependence on aid for research as well as teaching; (e) dependence on investment in education; ( $\mathrm{f}$ ) dependence of Third World social scientists on demand in the West for their skills. 
The paper argues that if considered in terms of the definition of indigenous social science, the scholarship and arguments of these two scholars can be seen to make significant contributions to the reframing of sociological language in India. However, according to the arguments presented by contemporary decolonial scholars, the contributions of these two scholars may be considered as a continuance of academic colonialism. Decolonial perspectives are associated with three interventions (from three different regions of the world), all three of which reconfigured Marxist ideas on the social structuring of knowledge and mediated it with a discussion on colonialism: the subaltern studies project (Chakrabarty 2000, 2013; Guha and Chatterjee 2010), the decolonial research program (Escobar 2007) and Paulin Houtondji's (1995, 1997, 2009) discussion on the colonial structuring of indigenous knowledge. While the decolonial research program subverted the existing dominant social science episteme of ' $\mathrm{I}$ ' and the 'other' by suggesting that the binaries of the 'coloniality of power' frames the episteme of the social sciences (Quijano 2000) and thereby affirms the need for the 'exteriority' approach (Dussel 1993, 2000), Hountondji (1995, 1997, 2009) argued for an endogenous approach to substitute indigenous social sciences because for him the colonial episteme is embedded within the latter. This perspective finds resonance in the work of Partha Chatterjee, one of the key interlocutors of the subaltern project who critiqued Indian nationalism through the concept of 'colonial difference'. Chatterjee (1986) argues that Indian nationalism is derivative in nature and reproduces colonial binaries in its discourse in new ways.

Following Chatterjee's argument, I claim that because the moorings of the Indian social sciences are in Indian nationalist thought, one can argue that the colonial episteme is reproduced through the mediation of nationalism within the social sciences in India (Patel 2020b). Thus, the 'social' in India has been constituted as traditional and defined in terms of the cultural and the spiritual and outside the economic and political. I argue that the constitution of these binaries that divide the social from the political and economic is part of the episteme of 'colonial modernity'. I further contend that this episteme has become embedded within mainstream sociological traditions of India: first, through the way colonial administrators-anthropologists conceived of India, and second, through its reproduction by Indian second-generation anthropologists and sociologists. As a consequence, over time, India has come to be conceived of as a traditional society operating in terms of its traditional dynamics rather than a society being reorganized through the power and domination of colonial capitalism, which used the cultural and the spiritual to legitimize its domination (Patel 2006, 2017, 2020b).

The paper contends that though M. N. Srinivas's field view approach departed from the Indological approach drawn from Orientalist positions practiced by colonial administrations and later by Indian scholars, his methodologies and theories continued to incorporate the main tenets of the colonial episteme. On the other hand, A. R. Desai's scholarship, based on Marxist class analysis, can be interpreted to suggest that he made a radical departure from mainstream sociology that was dominated by studies regarding caste, family and Hinduism (Patel 2007). For example, his work led to the framing of economic sociology, political sociology, the sociology of labor, the sociology of social movements, agrarian sociology and urban sociology. However, I suggest that despite his use of Marxist terminologies to examine contemporary social change in India, his scholarship continued to use Marxist theories of universal and linear history to argue 
that because capitalism was introduced by colonial powers, India can be seen as a class society. He took for granted the received Marxist concepts of class and power, did not engage with contemporary Indian historians who were reframing Marxism to understand distinctively Indian processes and avoided discussing the role played by cultural aspects in organizing nationalism as a dominant ideology. Though Desai's contribution comes from the juxtaposition of caste with class and the emphasis of the way capitalism played and continues to play a role in postindependence society, I contend that by ignoring the role played by caste and religion in class formation and class dominance, Desai also reproduced the colonial episteme by default ${ }^{3}$.

In the next two sections, I evaluate Srinivas's and Desai's ideas and plot their scholarship and the institutional responses that framed their scholarship. I also assess how their ideas have influenced the framing of postindependence sociology and social sciences. However, before presenting the work of these two pioneers, I elaborate how the assumptions of colonial modernity came to be mediated through nationalism in the scholarship of G.S. Ghurye (1893-1983) ${ }^{4}$ and D. P. Mukerji (1894-1961) ${ }^{5}$.

\section{Anthropologizing the social: the colonial perspective of India}

Contemporary Indian sociology is moored in the nineteenth century anthropology. Its main foundations were framed by colonial administrators in the context of growth and the spread of Orientalist positions in Europe that had been institutionalized in India a century earlier, first through the study of Indian languages and later, through them, the study of Indian society. It is thus no surprise that these ideas became the frame of reference for administrators a hundred years later when they were enjoined by the colonial state to create knowledge about Indian society. Two Eurocentric assumptions, which I collectively term colonial modernity (Patel 2017, 2020b), have shaped the disciplinary identity of anthropology in India: the first created a distinction between groups living in India from the spatial and cultural frames of the West and the second constituted these in an internal hierarchy using an Orientalist understanding of Hindu hierarchical systems.

Following Orientalist/racial principles, British civil servants and anthropologists and, later, Indian anthropologists placed the debate of identifying and designating these groups as 'castes' and 'tribes' within a discussion of 'stocks' or 'races' in relation to the Western notions of 'stock' and 'race'. To formulate these categories, they relied on evolutionary theory as well as Victorian social thought associated with 'race science'. In this regard, they were aided by the theory of the 'Aryan' (white or fair-skinned) invasion

\footnotetext{
${ }^{3}$ It is significant that Beteille, one of the key social anthropologists of the time and a colleague of Srinivas at the Department of Sociology of the Delhi School of Economics, argued that Marxism and sociology are irreconcilable and that Marxists cannot be sociologists. As a consequence, A. R. Desai found little recognition as a sociologist, and his first invitation to lecture at the department of the Delhi School of Economics came as late as the end of 1970s. He became the president of the Indian Sociological Society in 1980 (Patel 2007). ${ }^{4}$ Ghurye wrote 31 books and 47 papers and was the head of Bombay University's department of sociology for 35 long years. He initiated the idea of establishing the Indian Sociological Society and mobilized the support of colleagues for the same. He remained the society's president from 1951 to 1966 and was also the founder editor of its journal, the Sociological Bulletin.

${ }^{5}$ Mukerji was associated with the 'Lucknow School' of sociology—so called because he and his colleagues Radhakamal Mukherjee. D. N. Mazumdar and A. K. Saran were affiliated with the Department of Economics and Sociology at Lucknow University and promoted a different vision for sociology in India. He wrote 19 books and innumerable articles and was an inspiring teacher. He was considered a social critic, social philosopher and a culturologist (Joshi 1986; Madan 2011a, 2011b).
} 
of India, which grew out of the discovery of the Indo-European language family in the late nineteenth century. Hence, linguistic classification merged with racial classification to produce a theory of Indian civilization formed by the invasion of fair-skinned, civilized, Sanskrit-speaking Aryans, who conquered and partially absorbed the darkskinned savage aborigines and were later subordinated by other fair-skinned Aryans (Patel 2006).

This theory was critical in producing the basic division of groups in India into Aryan and non-Aryan races, now termed 'castes' and 'tribes'. What is of interest is the fact that while 'castes' were defined in the context of Hinduism as groups who cultivated land and had better technology and highly civilizational attributes, 'tribes' were defined in contrast to castes as peoples using primitive technology, living in interior jungles and having animistic religious practices. In the process, 'caste' and 'tribe' were made out to be a far more pervasive, totalizing and uniform concept than they were as practiced by precolonial Indians and were defined in terms of a religious order, which was not always the case among the actual groups being described. In fact, it has now been shown that ancient and medieval historiographers inform us that the groupings we identify as castes and tribes were groups that were shaped by political struggles and processes over material resources. In precolonial India, multiple markers of identity defined relationships between groups and were contingent on complex processes that were constantly changing and were related to political power.

The categories of caste and tribe were further defined once the colonial authorities organized the revenue settlements to facilitate an agrarian taxation system. British officials searched for a new classification to understand and assess the material conditions that organized groups within the Indian subcontinent. The rulers needed to create spatial units for the maintenance of law and order as well as for the regular collection of taxes once these were assessed, and three units were created in India: villages, estates and properties. These units had positions such as zamindars, patels, chaudhuris, talukdars, chiefs, rajas, nawabs and princes. The village was given a boundedness, making it almost like an 'island society' (first theorized by Radcliffe-Brown) in which communities of castes lived in harmony. This perception had come to be firmly embedded since then, as it resonated in many ways in both nationalist thought and sociological imagination. Thus, when empirical social science began developing from the 1940s onward, sociologists made the village the locale for understanding the caste system (Patel 2006). Colonial conquest and knowledge enabled both ways to rule and ways to construct what colonialism was all about: its own self-knowledge.

Colonial modernity, I suggest, is a discursive term/concept: that is, it is about not only the modernity experienced in the colony or in the period of colonialism but also the way colonialism constituted ideas, ideologies and knowledge systems of the 'natives' to refract and make invisible the 'modern' contours of the everyday experience of the people who were colonized. I also propose that in the case of India, this knowledge (a) was produced as part of colonial politics of rule, (b) was expressed and organized in terms of values that were in opposition to modernity, (c) used disciplinary practices such as Indology and ethnography to elaborate these positions, (d) was codified with the help of native intelligentsia, especially the Brahmins (e) thus it reflected the social order as represented by this group in its expressed articulations (in anthropology and later in social anthropology) and last, (f) it mitigated an examination of the way the 
classification systems of the state organized new forms of inequality in the colonial territory (Patel 2011a).

This classificatory schema based on the attribute of race and used to divide the peoples of the world found its own 'local' legitimation, articulation and 'voice' once colonial authorities imposed it to divide the 'natives'. This project found an expression (ironically and paradoxically) in the work of indigenous intellectuals in the subcontinent searching to find an identity outside of colonialism. For them, the immediate necessity was to locate 'our modernities' (Chatterjee 1997). Following Chatterjee, I have previously argued (Patel, 2020a that it was nationalism that mediated the construction of an identity for the intellectuals who were engaged with the colonial project. The question is now how nationalism mediated colonial principles.

Chatterjee has argued that unlike for Europeans, for whom "the present was the site of one's escape from the past", for indigenous Indian intellectuals, "it is precisely the present [given the colonial experience] from which we feel we must escape". As a result, the desire to be creative and search for the moorings of a new modernity is transposed to the past of India, a past ironically constructed by an orientalist colonial modernity. Thus, Chatterjee argues, "we construct a picture of "those days" when there was beauty, prosperity and healthy sociability. This makes the very modality of our coping with modernity radically different from the historically evolved modes of Western modernity" (Chatterjee 1997, p. 19). This past became rarefied to help in understanding the present and future; an orientalist imagination came to define the so-called indigenous expression. Obviously, racial constructions of 'difference' found a new legitimacy within a Brahminical casteist patriarchal ideology, as these two overlapped each other in the organization of the study of the social through newly reconstructed majoritarian and/or casteist positions (Patel 2007).

In his work explaining the three trends (traditional, traditional-modern and modern) of Indian nationalist thought, Bhikhu Parekh (1995) contended that there was little disagreement among these on the reasons for the present condition of the country. All three agreed that the nation's current degeneration and decadence were related to colonialism, domination by the British, the extraction and control of India's resources for imperialist purposes and the destruction of the nation's vitality and ideas by the colonial elite. The trends also agreed upon the necessity of a strong state to ensure a transition to modernity. However, there were differences regarding possible solutions, and these differences affected the subsequent identity of the discipline of sociology in contrast to those of economics and political science. Chatterjee has suggested that colonialism brought together two promises for the once colonized that led to both the "desire for power" and the "resistance to power": the struggle for "dreams of freedom" and, at the same time, the experience of being its victims and its episteme Chatterjee (1997, p. 19). If the disciplines of economy and political science drew from the modernist perspective of nationalism to frame the content of their disciplines, then sociology drew from the traditionalist current. If the first two ignored the way colonialism constituted the past to derive its legitimacy and saw its content as being defined by the future, that is, by modernity, sociology ignored the present to valorize the past.

"Traditionalists" argued for a need to draw out theories from the past from that of India's rich history and civilization. They asserted that though this civilization had suffered a decline, it was essentially fundamentally sound and was embodied with much 
strength. This strength had kept the Indian people together over centuries (except in the interregnum of the Muslim period), and these ideas would continue to bind the Indian people together in the future. Indian civilization and, thus, its society had a distinct history that evolved in interaction with its people and agencies. Indians and their social sciences needed to mobilize this creativity for their regeneration without losing their coherence and inner balance. Imitating the West and taking its language and values will not serve India or its people. India has to work out its own salvation in its own terms-under its own temperaments, traditions and circumstances (Bhattacharya, 201.1). This set of ideas framed sociological language in India when a new sociology department was established in 1919 at the University of Bombay. G. S. Ghurye, a Sanskritist, became the department head in 1924 and used an Orientalist methodology to discuss indigenous concepts that organized Indian traditions such as castes, tribes, the family system and Hinduism. Even today, his theories are considered to have foundational implications for the study of Indian society. How did he understand civilization and how did this affect the sociological study of India?

For Ghurye, culture and civilization were understood as being the same: as a complex set of ideas, beliefs, values and social practices (Upadhya 2002, 2007). His work rarely mentions any material practices. He eschewed any discussion of livelihoods, control over resources, or classes. Briefly, Ghurye argued that India was a civilization. He suggested that Indian civilization drew its unity from Hinduism and that Brahminism and its ideas and values provided the core values of this Hindu civilization. Brahmins were considered 'natural' leaders, torch bearers, the bearers of this civilization and its 'moral guides'. As a result, sociology in India was initiated with the Orientalist idea that the territory of the nation state is equivalent to its culture. Ghurye reproduced a design of Indian society as it was represented in Orientalist language. Thus, for him, Hindu civilization was structured around the caste system wherein if Brahmins were the most civilized, tribes were the most backward. Other religious groups, such as Muslims, Zoroastrians and Christians, deviated from this norm and needed to be assimilated into the Hindu fourfold system. The most difficult to assimilate would be the Muslims, who were perceived to be separate from Hindus in culture, ideas, and values and who were responsible for the current social evils of India. Indian society was seen as a set of rules that all Hindus followed, and Ghurye's understanding of law was based on a compendium of Hindu laws. It is no wonder that Upadhya states:

Ghurye's sociology adopted almost wholesale the Orientalist vision of Indian society as a Vedic civilisation and ultimately of the 'Aryan invasion'. And of Indian civilisation as Hindu .... (Upadhya 2002, p. 47).

D.P. Mukerji's (1894-1961) sociology tried to merge the two trends promoted by traditionalists and modernists. He was interested in assessing contemporary issues and problems affecting India. On the one hand, India was overburdened with poverty and backwardness, and on the other hand, its processes were determined by colonial exploitation. He was constantly troubled by the following question: how does one understand India's current economic problems, and what social science language does one need to construct to examine and evaluate them? Mukerji's answer was to reconstitute the 'traditionalist' debate mentioned above to create a new sociological language based 
on Indian conditions, circumstances and civilization that elaborated a sociological theory of and for India. To do so, he used a combination of Marxist methodology and hermeneutics.

This approach was significantly different than that embedded within the sociology constructed by G.S. Ghurye (mentioned above). Both the content of Ghurye's sociology (in terms of concepts) and his epistemic position emerged from a reconstructed understanding of the past, thus being akin to the traditionalist perspective. In Mukerji's case, his content was focused on the language of the present: the plight of agricultural laborers, forms of bondage, migrants and their problems and the contradictory impact of the processes of urbanization and industrialization in the context of colonialism. What Ghurye and Mukerji shared was an understanding of India being a civilization, an understanding constructed by Europeans and elaborated through Indological texts. For Ghurye and Mukerji, Indian modernity had to draw its precepts from its past.

For instance, Mukerji stated:

In the study of societies if the inevitability of transition from pre-industrial to industrial stage, from pre-capitalist to socialist stage introduces one aspect of the dynamic perspective, the contrast between the Indian (Asian) and the European civilization introduces another vital dimension of civilizational continuity and resilience. The attempt to precipitate the transition from the pre-industrial to the industrial and the pre-capitalist to the socialist stage without due regard to the compulsions of civilizational continuity are bound to generate counter forces of resistance to change (Joshi 1986: 1464).

Mukerji believed that cultural symbiosis is the outstanding feature of India's history. Change in India has proceeded along the lines of acceptance, adaptability, accommodation and assimilation rather than those of conflict. The British tried to create unity by expanding the market within the territory. However, it did not work because there are other principles structuring the culture of India. These are shantam (harmony-that which sustains the universe amidst all its incessant changes), shivam (welfare-the principle of coordination with the social environment) and adavaitam ('unity of unity' or synthesis). Madan (1994:9) suggests that Mukerji's sociology is sustained on these three cultural principles.

The modernist current of nationalism, on the other hand, traces the decay of contemporary India to its past, its embeddedness in a "repressive, exclusive and hierarchical caste system" that "stifled individuality and initiative and suppressed dissent" (Parekh 1995). It also bred hierarchy, as it accepted hereditary occupations, conferred power and status on the basis of birth rather than individual initiative and personal achievement, and discouraged enterprise. It was contended that these pasts fragmented the country and made it open to foreign invasions such as that of the British. Economists and political scientists as well as Marxists drew their concepts from this framework, as they attempted to comprehend how individual mobility and economic enterprise, rather than its traditional past, shaped the new India. Two kinds of social scientific perspectives, the liberal and the Marxist, developed within the modernist discourse and both used modern Western secular perspectives to comprehend contemporary India. 
This paper argues that while Srinivas continued the Ghurye tradition, Desai drew from the modernist current and ignored the role played by caste and religion together with traditional ideologies in his assessment of contemporary India. While the first was conservative in its orientation, the second, though presenting a radical analysis of contemporary India, continued to reflect the constructed binaries by bracketing out the cultural and the spiritual from its language. The paper assesses the implications of these positions on contemporary sociology in India.

\section{The Srinivasian sociology and its departures ${ }^{6}$}

There are three main aspects to Srinivas's sociology. The first is the framing of new concepts such as Sanskritization ${ }^{7}$, Westernization and dominant caste to explain social change in modern India. The second is the use of the perspective of social anthropology and thus of ethnography or 'field view' to assess these changes. The third is his affirmation that the village should become a site for understanding changes in India and thus for doing ethnography.

It is important to understand the context that defines Srinivas's theoretical and methodological departures. First, in response to the trend sweeping the world in the early 50 s that propagated that US sociology has created the most important theoretical paradigm for studying sociology, Srinivas not only raised objections to this trend but also argued for a different point of view and a distinct new position. In his opinion, the acceptance of the American version of doing sociology would be "a national intellectual disaster of the first magnitude" (Srinivas 1951:36). His position was in agreement with already established traditions inaugurated in early and mid-twentieth century on the one hand by G. S. Ghurye, Srinivas's mentor in his earlier days, and on the other by D. P. Mukherjee and Radhakamal Mukherjee ${ }^{8}$, both whom were concerned with building the foundations of sociology and anthropology from distinctive Indian material.

It is no wonder that Srinivas declared in 1952 that he saw his role as constructing a type of sociology that "we want" (Srinivas 1951:36). This phrase meant that he not only wanted to use the "Indian" experience to frame sociological principles but also wanted to set the terms of how to understand, evaluate and comprehend this experience and, consequently, elaborate new sociological principles attuned to the Indian experience. He was clear that sociology had to move away from the study of "preliterate communities" in India, this being the study of tribes, and from the enormous importance this perspective gave to "culture". His emphasis, in contrast, was on the Radcliffe-Brownian notion of "structure". He felt the need to study Indian society as a "totality", a study that would integrate the various groups in its interrelationship, whether those groups were tribes, peasants or various cults and sects. Social anthropology thus was the alternative for Indian sociologists.

\footnotetext{
${ }^{6}$ In this article, I draw on the work of two scholars and my own earlier work. These publications have made substantial critiques of Srinivas's oeuvre: Deshpande 2007, 2018, Oommen (1970, 2008) and Patel 1998, 2005. Additionally, I have drawn from the critiques made by various authors in the symposium on The Remembered Village (Madan 1978)

${ }^{7}$ See Charsley (1998a) on the growth of this concept in Srinivas's study on the Coorgs (Srinivas 1951), its later extension to the entire country and the methodological problems that this has created.

${ }^{8}$ On D. P. Mukerjee, Radhakamal Mukerjee, and the Lucknow School of sociology see Madan (2011a, b) and Thakur (2014a, b).
} 
In a seminal article published in 1954, Srinivas stated, 'An attempt is made in this essay to consider the relation between caste as it is in fact, and not as it is subsumed by the traditional concept of Varna' (Srinivas 2002: 166). This statement inaugurated a new method for assessing Indian society now known as the 'field view', in contrast to the earlier view known as the 'book view' (the Indological method). In a series of articles written in the 1950s, Srinivas elaborated the nature of the field view and its roots in the use of theory and methodology institutionalized in the structural-functional theory of Radcliffe-Brown and Malinowski's method of ethnography. At the same time, Srinivas adjusted their theories and methodologies to create, in his own words, a new version of the discipline of sociology and to remake it into social anthropology.

Of particular significance in understanding Srinivas's departures from the Indological method promoted by Ghurye are two articles 'Social Anthropology and Sociology' published in the Sociological Bulletin in 1952 and 'The Social System of a Mysore Village', (1955) in a book edited by McKim Marriott. In the paper 'Social Anthropology and Sociology ${ }^{\prime 9}$, Srinivas starts by distinguishing the social anthropological theory and method from those of physical anthropology. He indicates how the orientation of earlier Indian anthropology towards physical anthropology and ethnology tied it to an analysis of culture rather than of society and set it against an assessment of the latter's structure. He is also critical of practices in contemporary sociology in India, such as social philosophy and social work. Additionally, he is critical of contemporary sociological practices in the US that examine social problems and its use of the survey method. He thus argues for a need to incorporate anthropology into sociology to comprehend the specificity of contemporary India. From this logic flows the contention that there was no difference between sociology and social anthropology, which he understood in the following terms:

A modern sociologist regards a society as a system or unity, the various parts of which are related to each other. He considers that any single aspect of society abstracted from its matrix of sociological reality, is unintelligible except in relation to the other aspects. And even when he is writing only about a single aspect of a society like religion or law or morals, he brings to bear on his study and his knowledge of the total society. The importance of such a perspective cannot be overemphasized, and it can only be achieved by the intensive study over a long period of time, of a single small society (Srinivas 2002: 460).

It is therefore not surprising that he later admitted that,

It was from two micro studies, one of the Coorgs, ... and the other of the village Rampura, ... that concepts such as Sanskritisation and Westernisation, dominant caste, vote bank, and the book view versus the field view, emerged, and they continue to be used in the analysis of cultural and social change in different parts of India. It is well to remember here that in spite of its enormous diversity, India is one culture and this is visible in every village (Srinivas 2002: 566).

${ }^{9}$ This paper was republished in Srinivas's Collected Essays (2002). 
One of the first questions asked by social anthropologists, according to Srinivas, is about the primary unit of one's society. According to Srinivas, in the case of Indian society, this unit is caste. But what is caste? How do we understand it as a system? The word 'casta' was, as we know, adapted from Portuguese and Spanish words, and for many earlier sociologists, including G. S. Ghurye, it implies 'varna' (order, type, color), a word used regularly in Hindu scriptures (the book view). In an essay on varna and caste, Srinivas asks whether 'varna' has any empirical verifiability in India today. He initiates a methodological discussion on the caste system in India and suggests that if one does an empirical analysis (the field view) and if the anthropologist uses participant observation to understand and assess the way the people comprehend themselves, then caste means 'jati' (group defined through birth). When Srinivas discusses the caste system in 'The Social System of the Mysore Village', he does it by evaluating the system within the limits of the village.

However, while Ghurye's definition of caste remained couched in the Indological standpoint, Srinivas, using the field view and the empirical method oriented to ethnography, reorganized the study of caste to examine it with a new lens. Srinivas divides the population of the village by caste and occupation, examines the relationship of these castes with agriculture and connects the castes to their various occupations related to agriculture. The idea here is to show the organic integration of castes with each other and the way these relate with each other from a functional perspective elaborated by Radcliffe-Brown (Patel 1998). The system is shown to be flexible because of the integration of the parts to the whole. Further, Srinivas states that caste is best understood by focusing not only on the middle ranks but also in context of the internal ranking of each jati with the other. The ambiguity of rank and status allows for the mobility of groups. It is in this context that he coins a new concept-that of dominant caste-and makes it coterminous with the peasant caste that dominates the village.

What kind of ethnography does one get through such an approach? I have previously argued (Patel 2005) that this problem relates to the way ethnography was related to the functionalist paradigm and framed in the context of the principles of the British liberal ideology of the nineteenth century. Epistemically, ethnography made a distinction between subject and object and suggested that the subject, the social scientist, should distinguish herself from the object that she observed. In these circumstances, ethnography merely mirrors the subject's ideology. Research so produced becomes empiricist on the one hand and creates theoretical and methodological ambiguities on the other.

This can be seen in the way he elaborates the concepts of Sanskritization, Westernization and dominant caste. Srinivas suggests that (a) Indian civilization promoted the processes of change and that these related to caste mobility; (b) this mobility, through Sanskritization, was more possible for middle ranks of the caste system than for the lowest ranks; (c) Sanskritization implied adopting the behaviors and habits of the upper castes such as vegetarianism and the various customs and rituals of the Brahminic way of life; (d) because the British introduced new technologies, such as railways, the telegraph, the telephone, the press, radio communication systems and political ideas of representation, these allowed the proliferation of literacy, and Sanskritization process increased; and (e) another form of mobility was Westernization, which Brahmins mainly used by adopting British food habits, ways of life, behaviors and customs, which were obtained through education and then used to secure secular 
appointments as lawyers, teachers, bureaucrats, etc.; and (f) it is possible that this would lead other middle-ranking groups to emulate the Brahmins and the entire society becoming Western over time: "Sanskritisation is an essential preliminary to westernization" (Srinivas 2002:495) ${ }^{10}$

Srinivas contends that the caste system is far from a rigid system in which the position of each component caste is fixed for all time. Movement has always been possible, especially in the middle regions of the hierarchy. Members of a low caste are able, in a generation or two, to rise to a higher position in the hierarchy by adopting vegetarianism and teetotalism and by Sanskritizing their ritual and pantheon. In short, such individuals would take over, as far as possible, the customs, rites, and beliefs of the Brahmins, and the adoption of the Brahminic way of life by a low caste seems to have been frequent, though theoretically forbidden.

The first methodologically related ambiguity in Srinivas's oeuvre emerges as a result of the adjustment of the structural-functionalist approach in examining the interlinkages between caste and village. It is not clear what system he is studying, that of the village or caste. One presumes that he is discussing the caste system because of his earlier discussions on this theme. However, the village is also seen as a system, viz., the title of the paper. The lack of theoretical clarity on this issue leads to a teleological position whereby castes can only be understood sociologically as a system in the context of the village, while the village, in turn, can be assessed in the context of castes.

I have previously argued (Patel 2005) that the collapse of the social into the spatial also made possible an exclusion of groups and communities within the nation-state whose culture and practices could not be explained by the caste system, or, as Srinivas understood it, the dual system of 'varna' and 'jati'. The issue is not merely that of sociological conservatism, which many commentators view as deeply seated in functionalism, but is a larger question of the exclusion of a number of groups (tribes, religious, and ethnic groups other than castes) who define themselves differently and who are eliminated from the sociological space. Srinivas did not agree with the position that the village was a self-sufficient and isolated unit, but the emphasis on the village as a unit of ethnographic study made his paradigmatic principles contradict his avowed intentions (Patel 2005).

This ambiguity and contradiction flows into another arena-that of the study of social change. Particularly when examining mobility in modern India, he highlighted the continuous adaptive character of the caste system and its ability to adjust to modern processes of change and presented us with the two paths to mobility, Sanskritization (the emulation of the upper caste/dominant practices) and Westernization (the adoption of Western technology, education, 'lifestyle', values). He argues that Westernization is emulated by the Brahmins and some individuals in the upper castes, while Sanskritization is practiced by the lower castes. He almost provides us with a sequential theory of modernity quite similar to the modernization theories promoted by sociologists of North America in the 1950s and 1960s.

For Srinivas, the caste system of today contrasts with earlier versions of the system, which respected different occupations and ways of living. These changes make caste

\footnotetext{
${ }^{10}$ By late 1970s, with the growth of the Dalit movement (a movement of scheduled castes), Srinivas's formulations started to be termed Brahminic. See Charsley (1998a, b) and Pandian (2002).
} 
adaptive to new influences, modifying and moderating its characteristics, but do not transform it or lead it to completely vanish. This new upper caste/savarna vision of nation became institutionalized in many ways by the early 1970s, as Srinivas's views on caste in modern India, his ideas on social change in contemporary India, and his concept of dominant caste soon became part of the representations that defined the changes taking place during the Nehruvian period. His views also became the new academic language of practicing sociology, as he intervened and organized various initiatives that helped consolidate this position. He saw sociologists as taking a proactive role and argued that sociologists need to assess the processes of change, which he called "a quiet revolution, bloodless, continuous, progressively more inclusive, and faster" (Srinivas 1992), and to mediate between the public and government.

For instance, Srinivas was the chair of the UGC's first committee to draft a status report on the teaching of sociology and develop a model syllabi. He was also one of the five signatories of the Memorandum of Association that set up the Indian Council of Social Science Research (ICSSR), the premier funding body for social science research in India, the other four signatories being economists. Srinivas organized the ICSSR's first bibliographic survey of sociology and social anthropology in India, which charted out the specializations in the discipline, thereby directing research in defined areas.

In a continuation of these arguments and in terms of the main thesis of this chapter, I would like to highlight the fact that in Srinivas's work, the structure of Indian society determined by caste emerges as a kind of adjustment mechanism that expands and fits into macro changes as the changes enveloped jatis in search of new status positions. His perspective reproduces the colonial episteme that structured itself in terms of the theory of linear transition towards progressive changes in new ways. Colonial modernity proposed the theory of an evolution from a preliterate to a modern society.

The civilizational approach, borrowed from Ghurye (and, in turn, constructed from the abovementioned binaries) now reframed through structural functionalism, allowed Srinivas to posit an adaptive caste structure, which has perennially reproduced itself over centuries-a theory of incremental social change. Sociologists in India have since adopted this perspective as a way of identifying and practicing sociology in India, despite various differences regarding theory and approach. Thus, although India is modern, social anthropologists in India, such as Srinivas, have not studied its modernity; rather, they have studied its constructed traditions, a frame of dominant colonial modernity.

There have been extensive critical comments on Srinivas's concept of Sanskritization and Westernization from Marxist (the lack of recognition of the jati's placement in the economic structure, the processes of politics, and thus the relationship between politics and classes), Dalit (Pandian 2002) and feminist approaches. Today, ethnography has acknowledged the power dimension in the relationship between the insider and outsider as well as the politics involved in the construction of knowledge of the other. What is the implication of this sociology? In this sociology, we lose not only a sense of history but also the analysis of colonialism as a force and process of the destruction and creation of discourses regarding the binaries of modernity-tradition, capitalism as a generator of change that distributes rewards unequally, and development and planning as processes of an elite-organized ideology for refashioning society. Srinivas's sociology does not present us with concepts and theory that can evaluate and understand the 
contemporary processes of change and conflict in society. To access this repertoire, we have to accept that change, especially in the epoch of the world system, is exogenous, market-oriented and one that distributes rewards unequally and thereby constructs localities and regions as well as classes and ethnic groups in unequal relations with one another.

\section{A. R. Desai's Marxist sociology ${ }^{11}$}

The architecture of Desai's sociology follows a completely different genealogy than that of M. N. Srinivas. Desai was also a public intellectual but of a different kind than Srinivas. He wrote pamphlets and booklets in regional languages for those involved in struggles in addition to books and articles for those in academia. A. R. Desai was a Marxist and a sociologist who did not see a difference between the two. Unlike Srinivas, who assessed social systems to understand the continuity of the caste system as a specific civilizational social order, Desai was interested in analyzing contemporary social change to assess how it benefited a few. His work was a critique of mainstream nationalism and its political projects. Its focus was on the nature of the ruling class, their control of state institutions, and their constant efforts to use developmental programs to aid their own reproduction.

As discussed earlier, colonial modernity embodied an upper caste notion of the nation/community/samaj. This was a dominant metaphor in Ghurye's and Srinivas's sociology and remained embedded within this lineage as it developed further (see Oommen 2007). Desai contested these received conceptions of the nation in Social Background of Indian Nationalism (1948) by analyzing the ideology of Indian nationalism and showed how it represented the interests of dominant classes. He argued that nation and class have a contradictory relationship. While nationalism is a movement of various classes and groups forging one nation into a whole, the nation remains internally divided, with classes competing with each other to mark it with their own interests. The class at the helm imposes its own class interests on the movement, subordinating the interests of other classes to its own. Desai's sociology interrogated the normative projects of mainstream sociology/anthropology by redefining it as one that analyzes the relationship between nation, classes and power through a historical and interdisciplinary perspective.

The book Social Background of Indian Nationalism refashions three discrete positions into one. It explains first how colonialism intervened in the transition from feudalism to capitalism in India, destroying the growth of indigenous capitalism. It then moves on to evaluate the specificity of the nature of Indian precapitalist formation in the form of the caste system and then examines the role played by nationalism in confronting colonial capitalism. When it was published, this text presented a radical rethinking of class and nation together with colonialism and nationalism. Additionally, the analysis and interpretations given in this book also heralded a new perspective for doing sociology in India, which became evident after Srinivas's sociology was institutionalized in the late 1950s and 1960s. Desai's work insisted on the need to study the many interfacing macro processes that constitute contemporary capitalism and its inequities, arguing that this has to be done through a historical perspective and that an analysis of colonialism and nationalism is integral to this framework. While ignored by

${ }^{11}$ After he entered college in Baroda, Desai participated in the growing student movement. He was a member of the Communist Party from 1934-1939 and much later became a Trostikyite. In 1953, he joined the Revolutionary Socialist Party and remained a member until 1981. 
mainstream sociologists for a long time, this text was lauded by nationalist historians and political scientists as an exemplary model of the use of historical methods to assess contemporary social change ${ }^{12}$.

This early criticism of the colonial state increased when, in 1960, Desai published a sequel titled Recent Trends in Indian Nationalism (Desai, 1973) where he examined the nature of the postindependent state. For the first time, a sociologist in India reflected on the nature of the state from a sociological perspective. This text signaled a major departure for sociology that separated community and society by ignoring politics and the state. It examined the classes controlling the postindependent state and the role these played in developing capitalism. In the book, Desai set forth the terms for doing Marxist political sociology in India. The Indian state, Desai argued, was led by a weak bourgeoisie that had cemented a relationship with the feudal land-owning class and ruled through the received colonial state apparatus. To sustain an economically weak bourgeoisie and the contradictions emerging from its collaboration with the feudal landed elites and colonial institutions, the state in India assumed enormous powers for itself, taking initiative in intervening and participating in policies and programs necessary for the sustenance and legitimation of the power of the bourgeoisie.

This analysis led Desai to assess the planning process in India, especially the programs of land reform (which eliminated parasitical landlordism and created new classes, such as that of the rich peasants), community development and panchayati raj (Rural India in Transition, 1961). Desai believed that the state's focus on agrarian policy would create a class of agricultural capitalists, rich farmers and viable middle peasant proprietors directly associated with the state. From the 1970s onwards, A. R. Desai's perceptions of society and his assessment of the development of new processes led him to conduct further penetrating analyses of contemporary Indian class structure. Agitations, protests and struggles emerged in the countryside (the growth of the Naxalite/Maoist movement) and in urban arenas (the railway strike, women's movement and protests against slum demolitions). The working class, the traditional revolutionary force, was in the throes of change in terms of both its structure and its changing political consciousness. Simultaneously, politics was changing, and political parties were using caste and religious issues to mobilize the populace.

For Desai, the key to an assessment of all these processes lies in the analysis of the modern Indian state. It is important, he argued, that we ask why the state was playing an undemocratic role and why the state in India was using extra constitutional powers to repress the growth of democratic movements in the country? Answers to these questions, he asserted, can only come through a historical-comparative analysis of the statecivil society dynamics taking place in India. During these two decades, Desai initiated four organically related, complementary projects, three of which published collated information put together through the many travels he undertook to understand new movements and trends taking place across India. In the first project, he expanded on

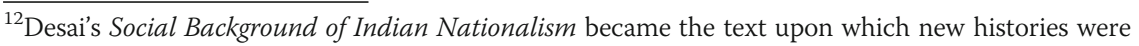
constructed. In the preface to his essays on nationalism, Bipan Chandra states, "The social character of the [national) movement, its origins, stages of development, the nature of social support and popular participation, the tactics and strategies evolved or used, and stages of development were not properly studied." There have been of course exceptions; for example, the works of A.R. Desai, R. Palme Dutt, and several economists during the 1920s and 1930s (Bipan Chandra 1979: vi). This was also later asserted by David Ludden (2001) when he argued that Desai was a precursor of the Subaltern School.
} 
his earlier work on rural transitions and attempted to capture the growth of new contradictions in rural India by documenting the struggles and agitations occurring in contemporary agrarian India. Titled Peasant Struggles in India (1979) and Agrarian Struggles in India after Independence (1986a), these sets of books immediately became and continue to be a major source of information on agrarian social movements in India and on the sociology of agrarian society in India. Second, during these decades, Desai initiated one of his most ambitious projects to date, that of documenting the history of the working-class movement in India.

This work is significant not only because it made visible a series of struggles and agitations among the working class that were previously unknown or undocumented but also because of its definition of the worker and the working class. Desai's study was not restricted to the industrial working class alone but encompassed all oppressed sections of society who were selling their labor power in the market. The change in definition is significant because Desai was the first to notice and highlight the 'informal sector' ${ }^{13}$ and the struggles of the unorganized workers later theorized about by economists and anthropologists. These volumes are now published. Third, Desai wrote a series of articles on the relationship between state and society in India that assessed the program policies and institutions of the state and simultaneously captured the social and political processes that they promoted.

These essays, published as State and Society in India: Essays in Dissent (1975) and India's Path to Development: A Marxist Approach (1984), not only laid out the terms of a Marxist sociology of development but also questioned the theories of modernization being used by social scientists. In these essays, Desai engages with the theories of dependency and underdevelopment (evaluated earlier in Desai 1971) to explain India's particular situation. These books contain an evaluation of the implications of imperialism, the planning process, the mixed economy, and the public sector on the one hand and the nature of casteist and communalist politics that have recently emerged on the other. The importance and significance of the state and the use it made of the repressive powers prompted Desai to initiate the last of his major projects (the fourth one), which occupied him through most of the 1980s. The result of this endeavor was a twovolume book, Violation of Democratic Rights of India (1986b) and Repression and Resistance in India (1990), which focused on the state and documented the way it restricted and curtailed the rights of the oppressed.

What is remarkable is the fact that for the first time Desai incorporates in his analysis the struggles not only of classes but also other of groups that cannot be defined as a class in Marxist language. For instance, he uses the categories 'rural poor', 'adivasis' (to denote tribes) and Dalits (to denote the ex-untouchables). Certainly, there is an effort here to move beyond Marxist categories and theorize new concepts within an overarching Marxist framework. In the 1970s and 1980s, these departures presented radical alternate conceptions of doing sociology. By asserting that sociology was an interdisciplinary social science rooted in the historical method that engages with the political economy approach, he questioned the culturist perspectives of mainstream sociology. He also affirmed the need to study power in its various dimensions within

\footnotetext{
${ }^{13}$ Jan Breman (1976) wrote about the informal sector based on his empirical work in Gujarat. See an updated version of his arguments (Breman 2016).
} 
dominant institutions (for example, the state) and in its invisible manifestations (through policies and developmental programs) as insidious expression (through communalism) together with its emancipatory potential (within social movements). He asserted that the discursive practices of the discipline should be organized around new concepts that draw on the narratives of those who are excluded. Desai wanted the sociologist to simultaneously be an archivist, analyst, and activist. However, for a large number of sociologists, including Marxists, Desai's project of sociology remained overtly ideological, political and oriented towards debates within the mainstream communist movement, particularly to the question of how to usher in a capitalist or socialist revolution.

More specifically, his work did not have a theoretical perspective from which to assess and examine the interface of class and caste or its linkages with gender ${ }^{14}$, ethnicity, and language and the complexities inherent in identity formation within the subcontinent. He was the first sociologist to distinguish between movements in terms of localities and regions, but his sociology generally collapsed the sociological construction of space into its political and administrative connotations, thereby reproducing the perspective of colonial modernity. Thus, like Srinivas, there remained slippages between territory, state and nation. Srinivas followed via Ghurye and the colonial anthropological traditions wherein sociology/anthropology valorized tradition, nation and upper caste identity. In Desai's case, this pattern emerged through his personal and political involvement with Indian nationalist and later Marxist movements and his catholic upbringing by a litterateur father who was influenced by Gandhism (Patel 2007: 421-2).

However, his lack of interface with contemporary Marxist interventions in the theory of classes has puzzled many. Several later Marxists, while applauding Desai's major contributions in focusing on the Indian state, were mystified by the triangular classification (rich peasants, middle-class farmers, and landlords) of the agrarian classes. Additionally, they questioned Desai's division of agrarian struggles into pre-Green Revolution and post-Green Revolution periods. The problems involve, on one level, empirical substantiation and starts from the first book onwards. In the Social Background of Indian Nationalism, Desai argues that precolonial India did not have private property and that villages in India were self-sufficient, autocratic, and nonprogressive, among other things. These errors were not retracted in the subsequent editions of the book. For instance, he uses the term 'rural sociology' (Desai, 1953) (popular among American sociologists) to depict peasant and agrarian societies. Surely, such usage does not advance scholarship or extend his political project (Patel 2007: 438), especially when he suggests that sociology is necessarily a politically oriented theory and that it cannot be value neutral (ibid.: 439).

Given that Desai could understand the normative projects in mainstream conservative sociology, why could he not assess the same in his own sociology? Why did he use Marxist concepts without interrogating their full connotation? Though he focused on the state, we find in his work neither a clear enunciation of the sociology of power nor, interestingly, a conversation with Gramsci. It is imperative to ask why in Desai, there

\footnotetext{
${ }^{14}$ His wife, sociologist Neera Desai, was one of the pioneers of women's studies in India and has acknowledged his help in theorizing the woman question in India. However, Desai himself did not write on this theme. On Neera Desai and other women sociologists' roles in fashioning women's studies in India, see Patel 2016a, b.
} 
was little to engagement with the methodological queries elaborated by the Frankfurt School and their interrogation of substantive issues regarding the nature of capitalism. They questioned naive positivism and empiricism and elaborated a critical theory that engaged with philosophical and methodological issues of sociology that examined the relationship between reason, science and power. It seems that Desai gave little attention to theory-building and merely adjusted empirical material to existing Marxist perspectives. This question emerges anew when we consider Desai as a historian. He was certainly aware of the debates among the New Left, as most of its members were influenced by Trotskyite ideas, regarding Marxist historiographies of transition, transformation and issues of class and state. However, he did not engage with these debates. As a result, his assessments of contemporary India were restricted to a macro universalistic analysis-an attempt to understand the play of social and political forces in the context of the nation state through an orthodox Marxist economist perspective.

What is Desai's legacy? For Desai, contemporary contradictions in India were located in property relations established in India through colonialism and nationalism. By arguing for a class analysis of nationalism, making visible the complexities of peasant movements in India (much before the subalterns made the study of peasants fashionable), or assessing communalism and claiming human rights for all, he showed a sensitivity to new trends emerging in Indian society and remained far ahead of his time. Additionally, because mainstream sociology perceived him to be an 'outsider' and because his interests were political, Desai's legacy remained on the margins in the construction of an alternate sociology of India. As a consequence, Desai's theories have not paved the way for new arguments to be presented and new theoretical positions to be articulated on themes that he explored, such as class and the laboring poor; nation and nationalism; development, state policies and poverty alleviation; and social movements. His theories cannot engage with the complexities that modernity has brought about in the Indian subcontinent. At best, one can state that his work as an archivist and documentalist helped to make the colonial and postcolonial experiences of exploitation visible. This challenged the conservative scholarship of Indian sociology and social sciences in general but could not set the terms for new theorizations for the discipline.

\section{Towards a conclusion}

Srinivas's sociology/social anthropology was constituted as a modern discipline, though it studied the 'social' differently from its modern variant: it continued the earlier ethnographic approach of studying "communities", now as segmented groups of jatis/castes. The modern orientation of his methodology, however, was reaffirmed because it promoted the 'field view' (empirical investigations) over the 'book view' (Indology), which was associated with colonialism, because it was indigenous insofar as it introduced participant observation as an "insider's perspective" of doing sociology, and because it affirmed a nationalist position. Last, it remained closely aligned with elite nationalist visions of society and therefore found resonance with the new ruling groups managing the nation state. The key leadership role that Srinivas and his colleagues at the Department of Sociology at the University of Delhi took on in the various institutions mentioned above also legitimized the universalization of his sociological vision, with other views such as those of sociologists from Lucknow, those of Marxist sociology from A. R. Desai and those of structural functionalism from Y. B. Damle being pushed in the 
margins. The diversity of perspectives that had been a key feature of the colonial period was now substituted by a master narrative. The social anthropology of the Srinivasian perspective was designed to represent the language of sociology (Patel 2011a).

As a consequence, the episteme of colonial modernity translated itself within the discipline of sociology to conceive of the nation as consisting of discrete groups called castes and to show that their diverse manifestations are the nation's signature characteristic and that economic development and planning will help to reframe the social and the cultural into modern India. Those groups that were not castes, such as tribes (both in Central India and the northeast of India) and minorities, were relegated to being backward and/or undeveloped. Henceforth, the hegemonic imagined visions of the state's ruling groups and their practices and dispositions became framework for doing social science, thereby not only silencing the recognition of marginalities of all kinds but also advocating their virtual disappearance in the language of sociology in the first few decades after independence. If one attribute of inequality was recognized by the new nation state, it was that of income, and it was related to a diffuse concept: poverty. Thus, it is no coincidence to note that the sociological language remained silent about the political moorings of this project, closely imbricated as it was with advanced metropolitan capitalism and given its embeddedness in the dynamics of capital accumulation on a world scale. Sociology took for granted the state and elite/ruling class discourses, agendas, loyalties and histories without problematizing them.

Additionally, this sociological tradition made possible the taken-for-grantedness of nation states' boundaries and made them natural boundaries to be protected militarily and fought for by the nation's people. Thus, this academic language territorialized the class, caste and gendered elite visions of the nation imbricated in the colonial episteme and used these as a lens to understand groups articulating difference within the nationstate. This orientation characterized the extensive production of sociological literature in India after independence. The literature was promoted through its many institutions, universities, research institutes and funding organizations, such as those of the state, as it expanded the system of higher education. This reinforced the close functional relationship between Indian academics and the system of higher education and, by extension, between the project of knowledge creation and the elite/upper class and caste/ savarna conceptions of nationhood. Unfortunately, what developed in India was a culture of professionalization that equated sociological knowledge to the state's policy orientations. This was unlike Europe, where social sciences developed through reflective and/or public intervention and its professionalization was related to the latter two orientations.

In what ways did sociologists in India react to these processes? By the late 1970s and early 1980s, it was clear (at least to some sociologists) that the discipline was facing a problem. For many, this problem was related to the methodology being used: that of participant observation. Saberwal (1983) was one of the first to criticize the sole reliance on participant observation to study social change in India. Such a method does not allow, he argued, its user to present a theoretically and methodologically challenged perspective to assess and examine the complex processes of conflict and consensus at work in India. The discipline needed a language that can study the complex macro interfaces between groups and processes that were often in a relationship of involution. Oommen (2007 [1983]) continued this argument by highlighting how the unit of 
analysis is critical in understanding contemporary modern processes. It is possible to examine family, caste and kinship through small units of study. However, this is not so in the case of critical issues of contemporary salience, such as the impact of partition on the Indian nation, or the question of why untouchability continues to be practiced in contemporary India. The same argument was reiterated by Dhanagare (1980, p. 25), who added to this debate by criticizing functionalist theory, which he argued could not assess conflicts and contestations that are becoming part of the Indian experience of modernity. Sociology, he argued, needs to be understood as social criticism. If historical analysis is used to assess the changes, then sociologists will be able to grasp the interrelationship between macro and micro processes.

For Saberwal (1983), the problem was also related to the way participant observation methods were conceptualized and institutionalized across departments within the teaching and learning processes. With non-trained teachers as interlocutions of the teaching process, description rather than analysis increasingly dominated the teaching of this method. This pattern became inflated with the simultaneous expansion of departments. In the 1950s, he stated, one idea in particular gained currency: modernity could be organized through the expansion of universities rather than by first creating a group of professionals who can understand the strengths and weaknesses of the perspectives and methodologies being used, and the universities would then transmit these in professional ways. To Saberwal, the problem thus relates to Indian notions of modernity. Thus, the expansion of universities bred its own contradictions, such as above. The contradictions were reinforced due to the disparity in accessing physical and human resources and to differential structures of academic autonomy, these being dependent on the university's legal character: that is, on it being a state university or a central university. Thus, the central universities were better funded, more autonomous and had a "national character". State universities needed to project a regional identity, had less funding and low staff numbers. This process became more complicated with the further expansion of state universities and the growth of a new state elite demanding that state universities teach in the language spoken in the region. Unfortunately, there was little to no intellectual investment in creating a vocabulary of social sciences in these regional languages. In these circumstances, this demand further impinged on the quality of the learning process and implicated what was taught and what was researched. Thus, the problem confronting the discipline was not merely one of its own academic language but also one of the limitations inherent within the modern institutional structures that sustained its practices. Increasingly, the sociologist/ethnographerteacher within departments encouraged doctoral students to use "insider" descriptive perspectives to generate monographs of "my village" and/or 'my community'. Over time, the study of sociology became a "soft experience" (Saberwal 1983, p. 308). Even though sociology in India could boast some of the best in the field, it was also producing a large mass of professionally untrained students and thus unqualified teachers/ researchers.

It is this legacy that contemporary sociologists in India are today contesting. 
Funding

No funding accepted for doing research on this paper.

\section{Availability of data and materials}

Use of secondary sources available in the public domain.

\section{Competing interests}

The author declares that there is no competing interest.

Received: 12 June 2020 Accepted: 10 November 2020

Published online: 04 January 2021

\section{References}

Alatas, S. H. (1972) The Captive Mind in Development Studies. Some Neglected Problems and the need for Autonomous Social Science tradition in Asia. International Social Science Journal, 24(1): 9-25.

Alatas, S.F. 2003. Academic dependency and the global division of labour in the social sciences. Current Sociology 51 (6): 599 613.

Atal, Yogesh. 1981. The call for indegenisation. International Social Science Journal 33 (1): 189-197.

Breman, Jan. 1976. A dualistic labour system? a critique of the 'informal sector' I, II \&lll: the informal sector. Economic and Political Weekly 11 (48): 1870-1876 11 (49): 1905-1908 and 11 (50): 1939-1944.

Breman, Jan. 2016. At work in the informal economy. A perspective from bottom up, Oxford India Paperbacks. Delhi: Oxford University Press.

Chakrabarty, Dipesh. 2000. Subaltern studies and postcolonial historiography. Nepantla: Views from South 1 (1): 9-32.

Chakrabarty, Dipesh. 2013. Subaltern studies in retrospect and reminiscence. Economic and Political Weekly 48 (12): 23-27.

Chandra, Bipan. 1979. Nationalism and colonialism in modern India. Delhi: Orient Longman.

Charsley, Simon. 1998a. Sanskritization: the career of an anthropological theory. Contributions to Indian Sociology 32 (2): $527-549$.

Charsley, Simon. 1998b. Sanskritisation: the career of an anthropological concept. Contributions to Indian Sociology 32 (2): 527-549.

Chatterjee, P. 1997. Our modernity. Rotterdam: Sephis and Codesria Publication.

Chatterjee, Partha. 1986. Nationalist thought and the colonial World. A derivative discourse? Delhi: Oxford University Press.

Desai, A.R. 1979. Peasant struggles in India. Delhi: Oxford University Press.

Desai, A.R. 1948. Social background to Indian Nationalism. New York: Oxford University Press.

Desai, A.R., ed. 1953. Rural Sociology in India. Bombay: Popular Prakashan.

Desai, A. R. (1979a [1961]) Rural India in transition. Bombay: Popular Prakashan.

Desai, A.R., ed. 1971. Essays on modernization of underdeveloped societies, Vols 1 and 2. Bombay: Thacker and Co. Ltd..

Desai, A. R. (1973 (1960). Recent trends in Indian nationalism. Bombay: Popular Prakashan.

Desai, A.R. 1975. State and Society in India: essays in dissent. Bombay: Popular Prakashan.

Desai, A.R. 1984. India's path of development: a marxist approach. Bombay: Popular Prakashan.

Desai, A.R., ed. 1986a. Agrarian struggles in India after independence. Delhi: Oxford University Press.

Desai, A.R., ed. 1986b. Violation of democratic rights of India. Bombay: Popular Prakashan.

Desai, A.R. 1990. Repression and resistance in India. Bombay: Popular Prakashan.

Deshpande, M.N. 2018. M. N. Srinivas (1916-1999). In The International encyclopedia of anthropology, ed. Hilary Callan, 1-4.

Deshpande, Satish. 2007. Fashioning a postcolonial discipline: M.N. Srinivas and Indian Sociology in Patricia Uberoi, Nandini Sundar and Satish Deshpande. In Anthropology in the East: founders of Indian sociology and anthropology, 496-536. Ranikhet: Permanent Black.

Dhanagare, D.N. 1980. In search of an identity. Seminar 254: 23-26.

Dussel, E. 1993. Eurocentrism and modernity (Introduction to the Frankfurt Lectures). Boundary 220 (3): 65-76.

Dussel, E. 2000. Europe, modernity and eurocentrism. Nepantla: Views from the South 1 (3): 465-478.

Escobar, A. 2007. Worlds and knowledges otherwise. The Latin American coloniality/modernity research programme. Cultural Studies 21 (2-3): 179-210.

Guha, Ranajit, and Partha Chatterjee. 2010. The small voice of history. Ranikhet: Permanent Black.

Hountondji, P. 1995. Producing knowledge in Africa today. The second Bashorun M. K. O. Abiola distinguished lecture. African Studies Review 38 (3): 1-10

Hountondji, P. 1997. Introduction in endogenous knowledge. Research trails, 1-42. Dakar CODESRIA.

Hountondji, P. 2009. Knowledge on Africa. Knowledge by Africans. Two perspectives on African studies. RCCS Annual Review 1: $121-131$.

Joshi, P.C. (1986) Founders of the Lucknow School and their Legacy. Ramakrishna Mukerjee and D. P. Mukerji. Some Reflections, Economic and Political Weekly, 21(33): 1455-1469.

Ludden, David. 2001. Reading Subaltern studies. Critical history, contesting meaning and the and the globalisation of South Asia. Delhi: Permanent Black.

Madan, M. N., ed. 1978. Symposium on the remembered village in the light of M. N. Srinivas's oeuvre, special issue, Contributions to Indian Sociology, 12 (1)

Madan, T. N. (1994) Tradition and Modernity in the Sociology of D. P. Mukerji in T. N. Madan Pathways. Approaches to the study of society in India, New Delhi: Oxford University Press

Madan, T.N. 2011 a. Radhakamal Mukerjee and his contemporaries: founding fathers sociology in India. Sociological Bulletin 60 (1): $18-44$.

Madan T.N. (ed.), (2011b) Sociology at the University of Lucknow: The First Half Century (1921-1975). Oxford in India Readings in Sociology and Social Anthropology.

Oommen, T.K. 1970. The concept of dominant caste: some queries. Contributions to Indian Sociology 4: 73-83.

Oommen, T. K. 2007 [1983]. Sociology in India. A plea for contextualisation. Sociological Bulletin, 32(2), 11-36. [Reprinted in Knowledge and society. Situating sociology and social anthropology. New Delhi: Oxford University Press]. 
Oommen, T.K. 2008. Disjunctions between field, method and concept: an appraisal of M.N. Srinivas. Sociological Bulletin 57 (1): 60-81.

Pandian, M.S.S. 2002. One step outside modernity. Economic and Political Weekly 37 (18): 1735-1741.

Parekh, B. 1995. Jawaharlal Nehru and the crisis of modernisation. In Crisis and change in contemporary India, ed. U. Baxi and B. Parekh, 21-56. New Delhi: SAGE Publications.

Patel, Sujata. 1998. The nostalgia for the village: M. N. Srinivas and the making of Indian social anthropology. South Asia 21 (1): 49-61.

Patel, Sujata. 2005. On Srinivas's 'sociology'. Sociological Bulletin 54 (1): 101-111.

Patel, Sujata. 2006. Beyond binaries. A case for self reflexive sociologies. Current Sociology 54 (3): 381-395.

Patel, Sujata. 2007. Towards a praxiological understanding of Indian Society: The Sociology of A.R. Desai in Patricia Uberoi, Nandini Sundar and Satish Deshpande. In Anthropology in the East: founders of Indian sociology and anthropology, 417443. Ranikhet: Permanent Black.

Patel, Sujata. 2011a. Introduction: ruminating on sociological traditions in India. In Doing sociology in India: genealogies, locations and practices, ed. Sujata Patel, xi-xxxviii. New Delhi: Oxford University Press.

Patel, Sujata. 2011b. Sociology in India: trajectories and challenges. Contributions to Indian Sociology 45 (3): 427-435.

Patel, Sujata. 2016a. Feminist challenges to sociology in India: an essay in disciplinary history. Contributions to Indian Sociology 50 (3): 320-342.

Patel, Sujata. 2016b. The challenge of doing sociology today. Economic and Political Weekly 51 (46): 33-40.

Patel, Sujata. 2017. Colonial modernity and methodological nationalism: the structuring of sociological traditions of India. Sociological Bulletin 66 (2): 125-144.

Patel, Sujata. 2020a. Sociology in India. The epistemes of colonial modernity and methodological nationalism. In Exploring socialbilities of contemporary India. New perspectives, ed. S. Patel, 25-50. Delhi: Orient Blackswan.

Patel, Sujata. 2020b. Sociology's encounter with the decolonial: The problematique of indigenous vs that of coloniality, extraversion and colonial modernity. Current Sociology. https://doi.org/10.1177/0011392120931143.

Quijano, A. 2000. Coloniality of power, eurocentrism, and Latin America. Nepantla Views from South 1 (3): 533-580.

Saberwal, Satish. 1968. Academic colonialism. The problem. Seminar 112: 10-13.

Saberwal, Satish. 1983. For a sociology of India. Uncertain transplants: anthropology and sociology in India. Contributions to Indian Sociology 17 (2): 301-315.

Srinivas, M.N. 1951. Religion and society among the Coorgs of South India. Oxford: Clarendon Press.

Srinivas, M.N. 1992. On living in a revolution and other essays. Delhi: Oxford University Press.

Srinivas, M.N. 2002. Collected essays. New Delhi: Oxford University Press.

Thakur, M. 2014a. Sociological traditions: contexts, claims and practices. Contributions to Indian Sociology 48 (3): 419-428.

Thakur, M. 2014b. The quest for Indian sociology: Radhakamal Mukerjee and our times. Shimla: Indian Institute of Advanced Study.

Uberoi, P. 2000. 'déjà vu?', Situating sociology: a symposium on knowledge, institutions and practices in a discipline. Seminar 495: $14-19$

Upadhya, Carol. 2002. The Hindu Nationalist Sociology of G. S. Ghurye. Sociological Bulletin 51 (1): 28-57.

Upadhya, Carol. 2007. The idea of Indian society: G.S.Ghurye and the making of Indian Sociology in Patricia Uberoi, Nandini Sundar and Satish Deshpande. In Anthropology in the East: Founders of Indian sociology and anthropology, 194-255. Ranikhet: Permanent Black.

\section{Publisher's Note}

Springer Nature remains neutral with regard to jurisdictional claims in published maps and institutional affiliations.

\section{Submit your manuscript to a SpringerOpen ${ }^{\circ}$ journal and benefit from:}

- Convenient online submission

- Rigorous peer review

- Open access: articles freely available online

- High visibility within the field

- Retaining the copyright to your article

Submit your next manuscript at $\boldsymbol{\nabla}$ springeropen.com 